\title{
PERTUMBUHAN EKONOMI DAN KETIMPANGAN ANTAR KECAMATAN DI KABUPATEN KLATEN (TAHUN 2003 - 2007)
}

\author{
Oleh: \\ Diana Wijayanti" \\ Arief Eko Pratono ")
}

\section{ABSTRAKSI}

Penelitian ini berjudul "Pertumbuhan Ekonomi dan Ketimpangan antar Kecamation di Kabupaten Klaten Tahtun 2003-2007". Penelitian ini bertujuan unituk menganalisis besarnya ketimpangan antar kecamatan di kabupaten Klaten dan untuk membuktikan apakah ada korelasi antara pertumbulhan ekonomi dengan ketimpangan ekonomi di Kabupaten Klaten pada tahun 2003-2007. Dengan menggunakan Tipologi Klassen, Indeks Williamson, Indeks Enteropi Theil dan Korelasi Pearson dengan menggunakan data Pendapatan Perkapita dan Jumlah Penduduk Kabupaten Klaten tahun 2003-2007 yang berstumber dari data BPS Kabupaten Klaten, hasil penelitian menunjukkan bahwa ada kecenderungan terjadi kenaikkan ketimpangan antar Kecamatan di Kabupaten Klaten. Hasil korelasi Pearson menunjukkan ketimpangan Williamson dan Theil memiliki penganih yang kuat dan positif terhadap pertumbuhan ekonomi.Untuk mengatasi hal tersebut, pemerintah Kabupaten Klaten dalam menentukan kebijakan pembangunan harus menggunakan beberapa strategi dengan mempertimbangan kondisi dan potensi masing-masing kecamatan di Kabupaten Klaten.

\section{A. LATAR BELAKANG}

Upaya pemerintah pusat untuk meningkatkan peran pemerintah daerah dalam pembangunan daerah sendiri, yang didukung oleh adanya undang-undang Pemerintah Daerah (Lembaga Negara Republik Indonesia Tahun 2004 nomor 125, Tambahan Lembaran Negara Republik Indonesia Nomor 4437) dan UU RI No.33 tahun 2004 tentang perimbangan keuangan antara pemerintah pusat dan pemerintah daerah, mendorong pemerintah daerah untuk mempercepat proses pembangunan dengan suatu model percepatan pembangunan yaitu Daerah Otonom yang disertai dengan kemandirian pengelolaan daerahnya.

Daerah Otonom adalah kesatuan masyarakat hukum dengan batas tertentu berwenang mengatur dan mengurus kepentingan masyarakat setempat menurut

-) Diana Wijayanti adalah Dósen Fakultas Ekonomi Universitas Islam Indonesia

*) Arief Eko Pratono adalah Alumni Fakultas Ekonomi Universitas Islam Indonesia 
Diana Wijayanti dan Arief Eko Pratono: Pertumbuhan Ekonomi dan Ketimpangan...

prakarsa sendiri berdasarkan aspirasi masyarakat. Tolak ukur dari keberhasilan pembangunan dapat dilihat dari pertumbuhan ekonomi, struktur ekonomi, dan semakin minimnya ketimpangan antar penduduk, antar daerah, dain antar sektor. Agar pembangunan ekonomi di daerah dapat selaras dan seimbang dengan pembangunan diskala nasional, maka perlu dilakukan betbagai kegiatan pembangunan sektoral yang harus disesuaikan dengan kondisi, prioritas, dan potensi yang dimiliki tiap daerah.

Beberapa daerah mengalami pertumbuhan yang sangat cepat namun beberapa daerah sangatlah lambat, disinilah peran serta pemerintah daerah untuk mengembangkan daerah yang tertinggal ini untuk maju. Pemerintah daerah memiliki beberapa permasalahan daiam penyelenggaraan proses pembangunan daerahnya, baik itu berupa pengambilan kebijakan atau mengusulkann strategi pembangunan daerahnya, mempebaiki lingkungan didaerahnya agar mampu mendukung perkembangan perekonomian.

Model pembangunan daerah yang dapat diterapkan pada kawasankawasan pengembangan merupakan salah satu alternatif yang dapat diterapkan pada daerah-daerah yang ada di Indonesia. Karena, dengan adanya pengembangan wilayah ini dapat merangsang kegiatan-kegiatan ekonomi, yang pada akhirnya turut berdampak terhadap pengembarigan kegiatan pembangunan wilayah. Adanya pengembangan tersebut juga akan diikuti oleh pembangunan infrastruktur, transportasi, komunikasi dan kelembagaan sosial yang secara alami dapat meningkatkan daya tarik investasi. Implikasinya terhadap kegiatan ekonomi yang terjadi di masyarakat adalah, bagaimana hasil produksi dari pusat-pusat pertumbuhan tersebut, dapat dipakai untuk melaksanakan kegiatan ekonomi yang berada di daerah sekitar pusat pertumbuhan (hinterland), sedangkan sisi lainnya adalah produksi hasil daerah hinterland tersebut juga dipakai untuk kegiatan ekonomi yang ada di pusat pertumbuhan. Oleh karena itu, dengan kebijakan yang diambil di pusat pertumbuhan tersebut dapat dijadikan sebagai generator untuk mendukung kegiatan ekonomi daerah sekitar. Kutub/ Pusat Pertumbuhan tersebut juga dapat diaplikasikan untuk menjembatani perbedaan peluang-peluang kegiatan ekonomi yang ada.

Tujuan dari pembangunan adalah naiknya pertumbuhan ekonomi melalui peningkatan Produk Domestik Bruto (PDRB) dengan adanya peningkatan PDRB berarti meningkat juga kemakmuran dan kesejahteraan masyarakat.

Salah satu faktor penting yang dapat menentukan keberhasilan proses pembangunan di Indonesia adaiah faktor perbedaan tingkat pertumbuhan ekonomi dan pendapatan perkapita regional. Pertumbuhan ekonomi yang dilihat berdasarkan nilai Produk Domestik Regional Bruto (PDRB) dari tahun ke tahun merupakan salah satu indikator dari keberhasilan pembangunan. Pengertian pertumbuhan ekonomi adalah kenaikan PDRB selama waktu tertentu,biasanya dihitung tipa tahun dan dinyatakan dalam bentuk persen (\%).

Dalam upaya merealisasikan pembangunan nasional tersebut, maka program pembangunan disusun atas dasar trilogi pembangunan yang terdiri dari pemerataan pembangunan,pertumbuhan ekonomi,dan stabilitas nasional, maka dari itu pembangunan nasional di Indonesia dilakukan sebagai upaya perwujudan suatu keadalian sosial yang bertujuan untuk : 
1. Mewujudkan kesejahteraan umum

2. Memajukan kesejahteraan bangsa .

3. Mewujudkan keadilan sosial bagi seluruh rakyat Indonesia

Dengan adanya peran Pemerintah Daerah untuk menjaga stabilitas perekonomian, serta mengembangkan dan mempercepat perekonomian daerah yang ada, membuat pemerintah daerah harus dapat melihat dan menentukan wilayah-wilayah mana yang secara ekonomi, sosial, dan kultural memiliki potensi untuk dikembangkan, baik itu potensi yang ada secara alami maupun potensi yang telah tumbuh dikarenakan adanya pembangunan. Hal ini penting bagi pemerintah agar para pengambil kebijakan tersebut, dapat lebih menempatkan pembangunan infrastruktur dan fasilitas-fasilitas lainnya pada lokasi tepat yang akan memberikan dampak-dampak yang positif terhadap perkembangan dan pertumbuhan pembangunan ekonomi.

Ciri-ciri dari daerah yang perekonomiannya meningkat secara terus menerus adalah; memiliki industri yang kuat dan maju, pertanian yang tangguh serta memiliki basis-basis pertumbuhan sektoral yang berpotensi besar (Nahrawi 2005: 5). Selain itu, pertumbuhan juga diperlukan untuk menggerakkan dan memacu pembangunan dibidang lainnya yang akan meningkatkan pendapatan masyarakat. Pertumbuhan yang ada jika diarahkan pada daerah-daerah yang telah memiliki potensi atau fasilitas wilayah juga akan mempercepat terjadinya kemajuan ekonomi, karena secara tidak langsung kemajuan daerah akan membuat masyarakat untuk mencari kehidupan yang lebih baik di daerah tersebut.

\section{B. KAJIAN PUSTAKA}

Alisjahbana dan Akita (2002), melakukan studi tentang kesenjangan pendapatan regional dengan membandingkan Cina dan Indonesia. Dengan menggunakan indeks Entropy Theil, hasil studi menunjukkan bahwa di Cina, kesenjangan meningkat dari sebesar 0,230 pada tahun 1995 menjadi 0,235 pada tahun 1997, dan kemudian terjadi peningkatan lagi pada tahun 1998 menjadi 0,249 . Sedangkan untuk Indonesia, penelitian dilakukan dengan dua periode yaitu tahun 1993-1997 (sebelum krisis) dan tahun 1997-1998 (selama krisis). Hasil studinya menunjukkan bahwa terjadi penurunan bahwa terjadi penurunan kesenjangan selama kisis ekonomi.

Wikestri meneliti Pertumbuhan Ekonomi dan Ketimpangan Antar Kecamatan di Kabupaten Tangerang tahun 2000-2004. Pada penelitian ini alat analisis yang digunakan adalah Tipologi Klasen, Indeks Ketimpangan Wiliamson, dan Korelasi Pearson. Penelitian ini menyimpulkan dengan menggunakan Tipologi Klasen, bahwa rata-rata PDRB per kapita kabupaten Tangerang sebesar Rp. $1.421 .703,86$ pada tahun $2000-2004$ dengan rata-rata pertumbuhan 0.99 persen. Berdasarkan dari hasil analisis pertumbuhan ekonomi dapat diklasifikasikan bahwa tingkat pertumbuhan per kecamatan di kabupaten Tangerang merata dikarenakan rata-rata tingkat pertumbuhan mendekati nol. (Wikestri, 2007) 
Diana Wijayanti dan Arief Eko Pratono: Pertumbuhan Ekonomi dan Ketimpangan...

a

Arif Wijaya melakukan penelitian tentang Pertumbuhan Ekonomi dan Ketimpangan Antar kecamatan di Kabupaten Kudus tahun 1999-2004. Pada penelitian ini alat analisis yang digunakan adalah Tipologi Klassen,Indeks Enteropi Theil, Korelasi Pearson. Penelitian ini menyimpulkan dengah menggunakan Tipologi Klassen ,bahwa Kabupaten Kudus Dibagi menjadi 4 Bagian :

- Daerah/Kecamatan yang Maju dan Cepat Tumbuh (High Growth And High Income)

- Daerah/Kecamatan yang Maju tapi tertekan (High Income but Low Growth)

- $\quad$ Daerah/kecamatan yang berkembang cepat (High Growth But Low Income)

- Daerah/Kecamatan yang relative tertinggal (Low Growth And Low Income) (Arif Wijaya,2007)

\section{LANDASAN TEORI}

Pertumbuhan ekonomi adalah proses kenaikan output perkpita dalam jangka panjang. Pertumbuhan ekonomi berkaitan dengan kenaikan output perkapita dengan adanya dua sisi yang perlu diperhatikan, yaitu sisi output totalnya (GDP) dan sisi jumlah penduduknya. Output perkapita adalah output total dibagi jumlah penduduk (Boediono, 1985: 1)

Pertumbuhan ekonomi diartikan sebagai kenaikan PDB/PNB tanpa mamandang apakah kenaikan itu lebih besar atau lebih kecil dari tingkat pertumbuhan penduduk,atau apakah perubahan struktur ekonomi terjadi atau tidak (Arsyad 2004 : 13).

Model Pertumbuhan Neoklasik menjelaskan hubungan antara pertumbuhan dan aliran faktor antar daerah. Model ini menghasilkan teori tentang konvergensi antar daerah.Perbedaan pertumbuhan regional dapat terjadi karena:

1. Stok modal yang berlainan antar daerah

2. Perbedaan perkembangan teknologi antar daerah

3. Pertumbuhan tenaga kerja yang berlainan antar daerah

Teori Pertumbuhan Endogen,menjelaskan bahwa pertumbuhan PDB sebenarnya merupakan suatu konsekuensi alamiah atas adanya ekuilibrium jangka panjang. Motivasi pokok dalam teori ini adalah menjelaskan ketimpangan pertumbuhan ekonomi antar Negara. Model ini memberikan perhatian pada peranan eksternalitas dalam penentuan tingkat hasil investasi permodalan. Investasi swasta dan publik di bidang sumberdaya atau modal manusia dapat menciptakan ekonomi eksternal (positif) yang mampu meningkatkan produktivitas. Teori ini menjelaskan terjadinya divergensi pola pertumbuhan ekonomi antar negara dalam jangka panjang.

Teori Pertumbuhan Jalur Cepat berpandangan setiap Negara/wilayah perlu memperhatikan sektor/komoditi apa yang memiliki potensi besar dan dapat dikembangkan dengan cepat, baik karena potensi alam maupun karena sektor itu memiliki competitive advantage untuk dikembangkan. Artinya, dengan kebutuhan modal yang sama sektor tersebut dapat memberikan nilai tambah yang besar, dapat berproduksi dalam waktu yang relatif singkat dan volume 
sumbangan untuk perekonomian juga cukup besar. Agar pasarnya terjamin,

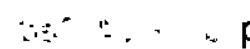
produk tersebut harus dapat menembus dan mampu bersaing pada pasar luar negeri. Perkembangan sektor tersebut akan mendorong sektor lain turut berkembang sehingga perekonomian secara keseluruhan akan tumbuh ( Tarigan,2005: 55).

Teori Growth Pole yang dikembangkan oleh ahli ekonomi Perancis, Francois Perroux (1950), menekankan bahwa proses modernisasi dari pertumbuhan ekonomi berbeda dari konsep stationer pertumbuhan keseimbangan. Argumentasinya adalah bahwa kenyataan mendasar dari spasial, sebagaimana sektoral, dalam pembangunan adalah pertumbuhan yang tidak terlihat dimana-mana secara simultan dan secara keseluruhan. Teori ini menjelaskan bahwa pembangunan memperbaiki titik-titik atau pole-pole pembangunan dan mempunyai intensitas yang bervariasi. Pola pertumbuhan regional terdiri dari sekumpulan industri yang diperluas, yang memperlihatkan kemajuan yang dominan dengan adanya aglomerasi yang disebabkan oleh ekonomi eksternal. Akselerasi pertumbuhan ekonomi regional dimungkinkan terjadi, berasal dari pole tertentu dan faktor ekonomi eksternal menyebabkan akselerasi prosies pertumbuhan di seluruh wilayah.

\section{HASIL DAN ANALISIS}

Tipologi Daerah
Alat analisis tipologi daerah digunakan untuk mengetahui klasifikasi daerah
berdasarkan dua indikator, yaitu pertumbuhan ekonomi dan pendapatan atau
produk domestik regional bruto (PDRB) per kapita. Dengan menentukan rata-
rata pertumbuhan ekonomi sebagai sumbu vertikal dan rata-rata produk domestik
regional bruto ( PDRB ) perkapita sebagai sumbu horizontal.
Objek dalam penelitian ini ialah seluruh kecamatan di Kabupaten Kiaten.
Dengan analisis tipologi daerah,seluruh kecamatan di Kabupaten Klaten dapat
dibagi menjadi empat klasifikasi, yaitu : daerah atau kecamatan yang maju dan
tumbuh (high growth and high income), daerah atau kecamatan yang maju tapi
- tertekan (high income but low growth), daerah atau kecamatan yang berkembang
cepat (high growth but low growth), daerah atau kecamatan yang relatif tertinggal
(low growth and low income). Untuk mengetahui rata-rata produk domestik re-
gional bruto ( PDRB ) perkapita dan pertumbuhan ekonomi kecamatan di
Kabupaten Klaten pada tahun 2003 - 2007 dapat dilihat pada tabel 1. Pada
tabel tersebut Kecamatan Klaten Tengah adalah kecamatan yang memiliki rata-
rata PDRB tertinggi. Sedangkan untuk rata-rata PDRB terendah adalah
kecamatan Bayat Selama tahun 2003-2007 PDRB rata-rata Kabupaten Klaten
adalah 3,246,678.33, dengan rata-rata pertumbuhan ekonomi sebesar 4.35\%.


Diana Wijayanti dan Arief Eko Pratono: Pertumbuhan Ekonomi dan Ketimpangan....

Tabel 1

Tabel PDRB per Kapita (Rp:) dan Laju Pertumbuhan Ekonomi (\%) Tiap Kecamatan di Kabupaten Klaten Periode 2003 - 2007

\begin{tabular}{|c|c|c|c|c|c|}
\hline No & Kecamatan & Simbol & $\begin{array}{c}\text { PDRB Per kapita } \\
\text { (Harga Konstan } \\
2000)\end{array}$ & $\begin{array}{l}\text { Pertumbuhan } \\
\text { Ekonomi (\%) }\end{array}$ & Kuadran \\
\hline 1 & Prambanan & Prm & $3,358,627.14$ & 10.14 & I \\
\hline 2 & Gantiwarno & Gwn & $2,347,149.67$ & 6.80 & II \\
\hline 3 & Wedi & Wed & $2,615,998.62$ & 12.91 & II \\
\hline 4 & Bayat & Byt & $1,495,867.66$ & 4.54 & II \\
\hline 5 & Cawas & Cws & $2,277,098.39$ & 3.21 & II \\
\hline 6 & Trucuk & Tck & $3,393,595.79$ & -4.88 & III \\
\hline 7 & Kalikotes & Kkt & $2,298,632.07$ & 5.93 & II \\
\hline 8 & Kebonarum & Kbrm & $2,477,607.78$ & 9.16 & II \\
\hline 9 & Jogonalan & Jgn & $3,231,578.59$ & 3.15 & II \\
\hline 10 & Manisrenggo & $\mathrm{Msr}$ & $3,441,596.01$ & 10.33 & $I$ \\
\hline 11 & Karangnongko & Knk & $2,151,976.48$ & 4.12 & II \\
\hline 12 & Ngawen & Ngn & $2,428,585.52$ & 5.45 & II \\
\hline 13 & Ceper & $\mathrm{Cpr}$ & $5,445,439.72$ & -5.04 & III \\
\hline 14 & Pedan & Pdn & $3,079,567.07$ & -0.65 & IV \\
\hline 15 & Karangdowo & $\mathrm{Kdw}$ & $1,885,139.72$ & 6.18 & II \\
\hline 16 & Juwiring & Jwr & $2,289,896.54$ & 11.34 & II \\
\hline 17 & Wonosari & Wsr & $2,216,859.20$ & 4.67 & II \\
\hline 18 & Delanggu & Dlg & $4,496,653.07$ & -1.31 & III \\
\hline 19 & Polanharjo & Phj & $2,438,615.18$ & 1.45 & II \\
\hline 20 & Karanganom & Kam & $2,008,790.75$ & -0.50 & IV \\
\hline 21 & Tulung & Tlg & $2,397,854.07$ & -0.12 & $\mathrm{IV}$ \\
\hline 22 & Jatinom & $\mathrm{Jtn}$ & $2,035,855.87$ & 7.22 & II \\
\hline 23 & Kemalang & $\mathrm{Kml}$. & $2,057,585.94$ & -0.92 & IV \\
\hline 24 & Klaten Selatan & Kls & $5,855,444.45$ & 11.46 & I \\
\hline 25 & Klaten Tengah & Klt & $9,228,247.72$ & 3.03 & III \\
\hline 26 & Klaten Utara & Klu & $7,459,373.44$ & 5.44 & I \\
\hline & Jumlah & & $84,413,636.47$ & 113.11 & \\
\hline & Rata-rata & & $3,246,678.33$ & 4.35 & \\
\hline
\end{tabular}

Sumber: Data BPS, diolah

Berdasarkan tabel 1 mengenai rata-rata pertumbuhan per kapita dan ratarata pertumbuhan. Maka pola dan struktur perekonomian seluruh kecamatan di kabupaten Klaten pada tahun 2003-2007 diklasifikasikan menjadi empat, untuk lebih jelasnya lihat gambar 1. 


\section{Gambar 1}

Pola dan Struktur Perekonomian di Seluruh Kecamatan di Kabupaten Klaten periode 2003-2007

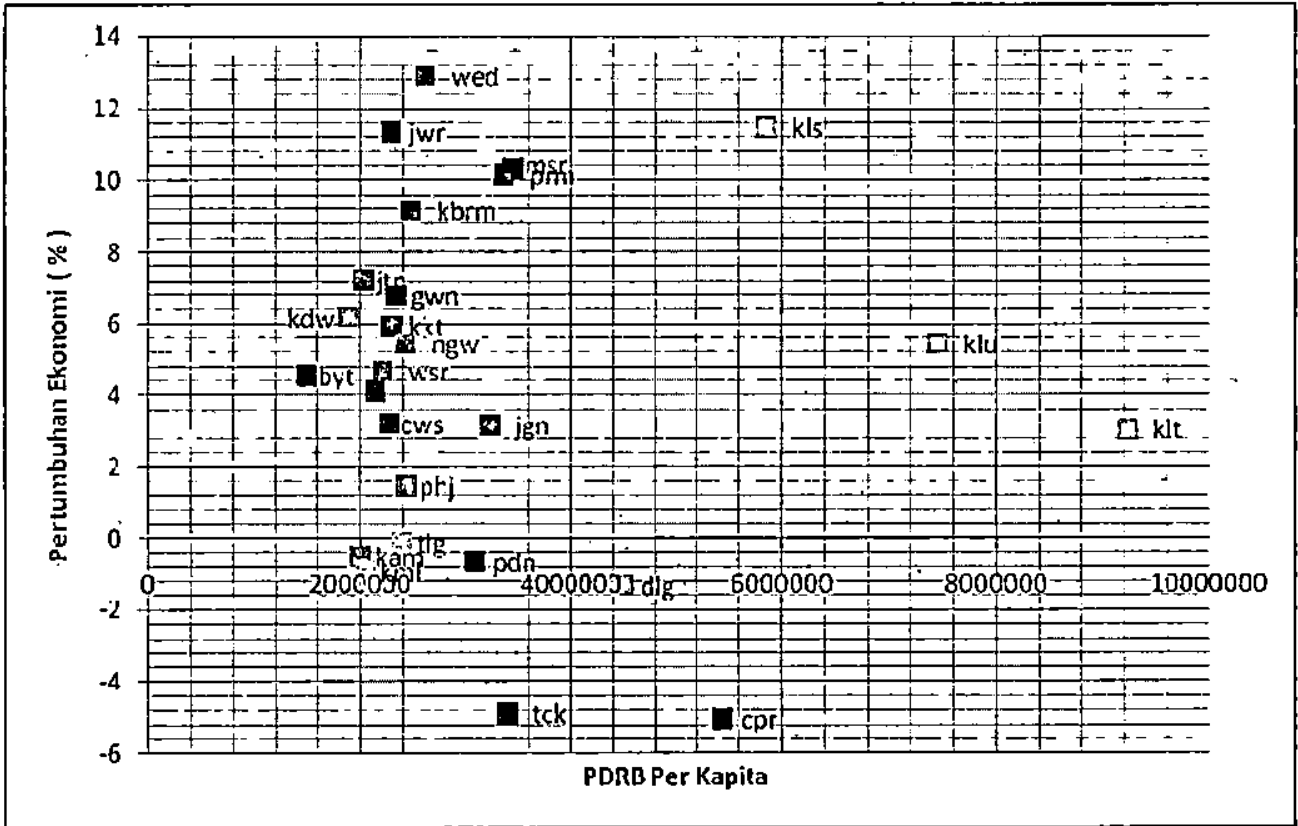

Dengan Tipologi daerah kecamatan di kabupaten Klaten dapat diklasifikasikan menjadi empat bagian :

\section{Daerah maju dan cepat tumbuh (high growth and high income)}

Kecamatan yang termasuk kategori maju dan tumbuh (high growth and high income), adalah Prambanan, Manisrenggo, Klaten Utara, dan Klaten Selatan. Kecamatan Prambanan adalah kecamatan yang berbatasan langsung dengan kabupaten Sleman,kecamatan Kalasan,Daerah Istimewa Yogyakarta. Di Prambanan juga terdapat obyek wisata berupa candi Prambanan. Meskipun dalam perhitungan wilayah Candi Prambanan masuk dalam Daerah Istimewa Yogyakarta,namun karena adanya Obyek Wisata ini,banyak bermunculan tempat-tempat usaha untuk membelanjakan oleh-oleh daerah setempat. Kecamatan Manisrenggo adalah daerah yang menghasilkan Palawija. Kecamatan Klaten Utara dan Klaten Selatan adalah daerah pengembangan kota Klaten,sehingga banyak pelaku-pelaku bisnis menginvestasikan modalnya didaerah ini. Kecamatan-kecamatan tersebut pada umumnya merupakan daerah yang sudah maju dari segi pembangunan maupun kecepatan pertumbuhan.

\section{Daerah Maju tapi Tertekan (high income but low growth)}

Kecamatan yang masuk dalam Daerah Maju Tapi tertekan adalah Kecamatan Gantiwarno, Wedi, Bayat, Cawas, Kalikotes, Kebonarum, Jogonalan, Karangnongko, Ngawen, Karangdowo, Juwiring, Wonosari, Polanharjo, Jatinom. Kecamatan Gantiwarno, Bayat, dan Cawas. Kecamatan- 
kecamatan tersebut adalah daerah yang memiliki lahan pertanian yang luas. Kecamatan Gantiwarno lebih berpotensi pada pertanian. Namun didaerah Gantiwarno juga terdapat objek wisata religi yaitu Goa Sriningsih. Kecamatan Bayat selain pertanian juga merupakan daerah Industri Gerabah dan Batik. Dan didaerah Bayat inii juga terdapat beberapa objek religi salah satunya adalah makam Sunan Pandanaran. Kecamatan Cawas selain merupakan daerah pertanian namun juga daerah penghasil ukir-ukiran kayu. Kecamatan Wedi merupakan daerah pertanian dan perdagangan di wilayah selatan Kabupaten Klaten. Kecamatan Jogonalan dan Kebonarum merupakan daerah yang digunakan sebagai daerah Transportasi untuk wilayah DIY dan Surakarta. Selain itu daerah Jogonalan adalah daerah perdagangan dan memiliki industri Pabrik Gula GONDANG. Kecamatan Karangnongko, Ngawen, Polanharjo, dan Jatinom adalah daerah perdagangan daerah utara Kabupaten Klaten. Kecamatan yang masuk dalam kategori ini umumnya relatif maju namun beberapa tahun mengalami pertumbuhan yang relatif kecil.

\section{Daerah Berkembang cepat (high growth but low income)}

Kecamatan yang termasuk dalam daerah Berkembaing cepat adalah Kecamatan Trucuk, Ceper, Delanggu, dan Klaten Tengah. Kecamatan Delanggu adalah daerah penghasil beras, dan merupakan daerah indu'stri. Kecamatan Ceper masih sama dengan kecamatan delanggu penghasil beras namun industri yang ada bukanlah industri pengolahan padi menjadi beras namun industri genting. Kecamatan Trucuk merupukan daerah industri kerajinan mebel. Kecamatan yang masuk dalam kategori ini umumnya memiliki potensi pengembangan yang sangat besar, tetapi masih belum diolah sepenuhnya secara baik. Walaupun tingkat pertumbuhan ekonomi daerah kecamatan yang masuk dalam kategori ini sangat tinggi, namun tingkat pendapatan perkapita yang mencerminkan tahap pembangunan yang telah dicapai sebenamya masih relatif rendah dibandingkan dengan daerah-daerah lain.

\section{Daerah relatif Tertinggal (low growth and low income)}

Kecamatan yang masuk dalam kategori ini adalah kecamatan yang memiliki tingkat pertumbuhan dan pendapatan perkapita yang berada di bawah rata-rata. Kecamatan Karanganom, Tulüng, Kemalang, dan Pedan adalah Kecamatan yang masuk dalam kategori ini. Kecamatan Pedan walaupun memiliki industri peleburan baja,namun daerah ini sudah berubah dari daerah industri menjadi pertanian. Daerah kecamatan Karanganom merupakan daerah pertanian namun belum memiliki potensi yang lebih untuk dikembangkan didaerah ini. Daerah kecamatan Tulung adalah daerah yang masih berupa pedesaan tertinggal, namun adanya industri air minum AQUA didaerah ini sedikit meningkatkan pemasukan di Kecamatan Tulung ini.

\section{Indeks Williamson}

Unituk memberikan gambaran yang lebih baik tentang kondisi dan perkembangan pembangunan daerah di Kabupaten Klaten, maka pemerataan PDRB perkapita antar kecamatan di analisis menggunakan Indeks Williamson. Nilai Indeks. Williamson jika semakin kecil atau mendekati nol menunjukan 
ketimpangan yang kecil pula atau dengan kata lain semakin merata, dan bila semakin jauh dari nol menunjukan ketimpangan yang semakin melebar (Mudrajad Kuncoro, 2004 : 134).

Hasil perhitungan indeks Williamson antar kecamatan di kabupaten Klaten pada tahun 2003 sampai dengan 2007 dapat dilihat pada tabel 2.

Tabel 2

Indeks Williamson Kabupaten Klaten 2003-2007

\begin{tabular}{|c|c|}
\hline Tahun & Indeks Williamson \\
\hline 2003 & 0.5873 \\
\hline 2004 & 0.6026 \\
\hline 2005 & 0.5102 \\
\hline 2006 & 0.5385 \\
\hline 2007 & 0.5362 \\
\hline rata-rata & 0.5549 \\
\hline
\end{tabular}

Sumber : Data-BPS, diolah

Dari tabel 2 dapat diketahui bahwa nilai ketimpangan PDRB per kapita antar Kecamatan di Kabupaten Klaten selama periode 2003-2007 masuk pada kategori sedang. Apabila nilai Indeks berada dibawah 0,30 bisa dikatakan ketimpangan yang terjadi sangatlah kecil. Apabila nilai Indeks berada di 0,40 dan 0,69 maka ketimpangan yang terjadi sedang. Apabila nilai Indeks berada diatas 0,70 , ketimpangan yang terjadi tinggi. Selama periode 2003-2007 ratarata ketimpangan PDRB perkapita antar Kabupaten mencapai nilai 0,5549.

Ketimpangan yang terjadi di Kabupaten Klaten tersebut disebabkan pembangunan yang terpusat pada beberapa daerah. Ketimpangan yang terjadi di Kabupaten Klaten dapat diihat pada Gambar 2.

\section{Gambar 2}

\section{Grafik Indeks Williamson Kabupaten Klaten periode 2003-2007}

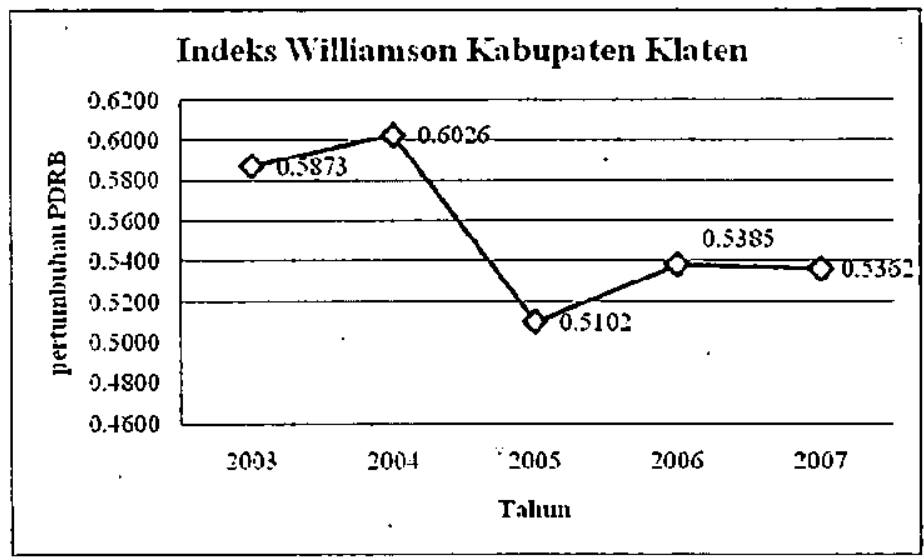

Sumber : Data BPS, diolah 
Diana Wijayanti dan Arief Eko Pratono: Pertumbuhan Ekonomi dan Ketimpangan...

口us u

Dari gambar 2 tersebut, dapat dijelaskan bahwa pada tahun 2003 ketimpangan yang terjadi sebesar 0,5873. Namun pada tahun 2004 sempat meningkat menjadi 0,6026. Namun pada tahun 2005 mengalami penurunan ketimpangan yang cukup tinggi menjadi 0,5102 . Hal ini disebabkan oleh adanya pemerataan ekonomi diwilayah Klaten. Pada tahun 2006 mulai naik kembali menjadi 0,5385, hal ini dikarenakan adanya Bencana Gempa Bumi yang melanda Kabupaten Klaten. Dengan adanya Gempa Bumi,pembangunan di beberapa daerah mulai naik kembali dengan adanya investor. Bantuan yang ada selain digunakan untuk membangun infrastruktur yang rusak, juga digunakan untuk membangun roda perekonomian di beberapa daerah yang terkena efek gempa. Dengan adanya gempa, pembangunan yang terjadi menjadi lebih terfokus didaerah-daerah pasca gempa untuk meningkatkan kembali roda perekonomian di daerah tersebut. Pada tahun 2007 ketimpangan menjadi 0,5362.

\section{Indeks Enteropi Theil}

Untuk mengetahui besamya ketimpangan yang terjadi di Kabupaten Klaten dapat juga dianalisi menggunakan Indeks Enteropi Theit. Nilai Indeks Enteropi Theil jika semakin besar atau menjauh dari nol berarti menunjukan ketimpangan yang semakin besar dan bila Indeks Enteropi Theil semakin kecil atau mendekati nol maka ketimpangan akan semakin rendah atau atau dengan kata lain merata.

Hasil perhitungan Indeks Enteropi Theil antar Kecamatan di Kabupaten Klaten dapat dilihat pada tabel 3.

Tabel 3

Indeks Enteropi Theil Kabupaten Klaten Periode 2003-2007

\begin{tabular}{|c|c|}
\hline Tahun & Indeks Enteropi Theil \\
\hline 2003 & 0.0756 \\
\hline 2004 & 0.0766 \\
\hline 2005 & 0.0748 \\
\hline 2006 & 0.0810 \\
\hline 2007 & 0.0788 \\
\hline Rata-rata & 0.0774 \\
\hline
\end{tabular}

Sumber : data BPS,diolah

Dari data tabel 4.3 diatas dapat dilihat dan diketahui bahwa ketimpangan pendapatan di Kabupaten Klaten pada periode 2003-2007 merata, dengan ratarata ketimpangan PDRB sebesar 0,0774 bisa dikatakan ketimpangan di kabupaten Klaten merata.

Seperti halnya Indeks Williamson, Indeks Enteropi Theil juga menunjukan kecenderungan peningkatan ketimpangan yang terjadi di kabupaten Klaten pada periode 2003-2007. Gambar yang menunjukan ketimpangan pendapatan di Kabupaten Klaten dapat juga dilihat pada gambar 3. 
Gambar 3

Grafik Indeks Enteropi Theil Kabupaten Klaten Periode 2003-2007

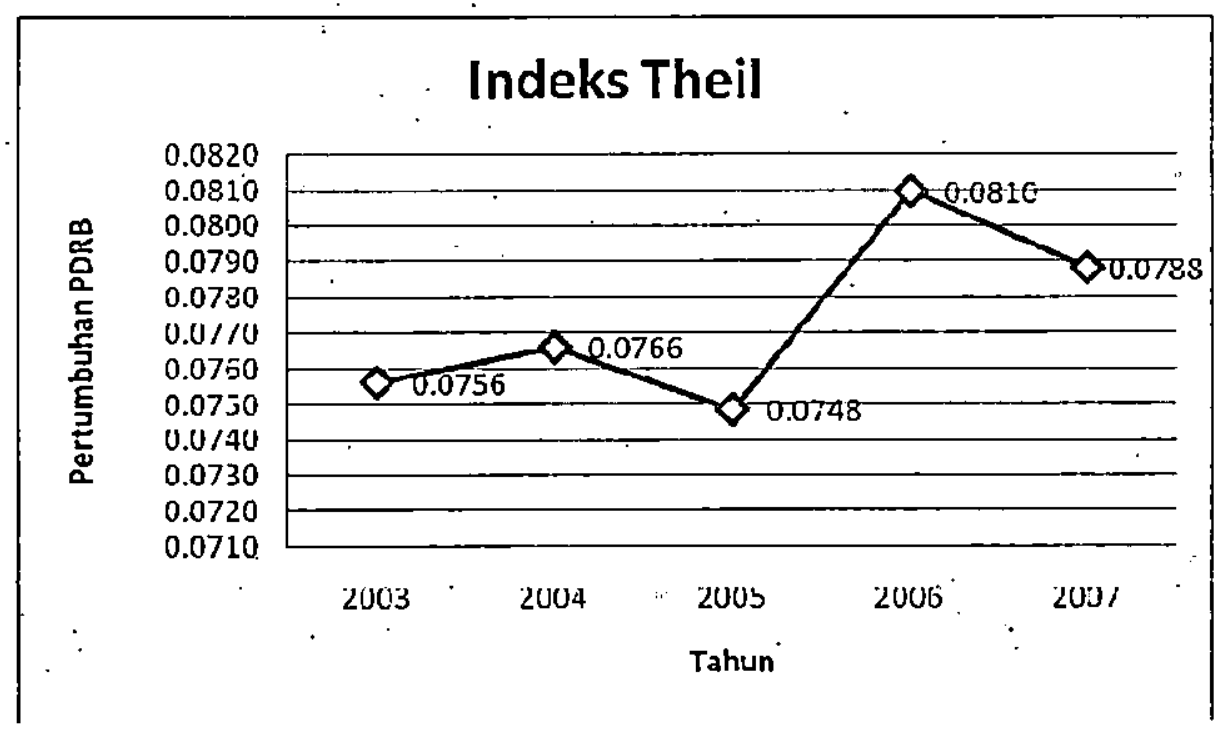

Sumber : Data BPS, diolah

Pada Gambar 4.3 dapat disimpulkan bahwa terjadi ketimpangan Pendapatan di kabupaten Klaten pada periode 2003-2007. Pada tahun 2003 Kabupaten Klaten ketimpangan yang terjadi sebesar 0,0756 dan pada tahun 2004 meningkat menjadi 0,0766 . Namun pada tahun 2005 terjadi penurunan ketimpangan hingga 0,0748 , hal ini disebabkan adanya pemerataan ekonomi di beberapa daerah yang menyebabkan kesenjangan antar daerah berkurang. Di tahun 2006 ketimpangan yang terjadi meningkat menjadi 0,0810. Besarnya ketimpangan yang terjadi 2006 dikarenakan adanya bencana alam berupa gempa bumi pada bulan Mei 2006. Fokus daerah yang terkena efek gempa untuk meningkatkan perekonomian daerah tersebut terhambat dikarenakan daerah tersebut lebih memfokuskan pada pembangunan infrastruktur yang rusak akibat gempa. Pada tahun 2007 menjadi 0,0788 . Hal ini dapat dikatakan dalam kurun waktu lima tahun kabupaten Klaten mengalami ketimpangan pendapatan yang merata.

\section{Korelasi Pearson}

Untuk mengetahui hubungan antara pertumbuhan ekonomi dengan ketimpangan antar kecamatan di kabupaten Klaten, dalam hal ini pertumbuhan PDRB dengan Indeks Williamson dan pertumbuhan PDRB dengan Indeks Enteropi Theil maka digunakan Metode Korelasi Pearson. Dua variabel dikatakan berkorelasi apabila perubahan pada variabel yang satu akan diikuti perubahan pada variabel yang lain dengan arah yang sama atau dapat pula berlawanan.

Hasil dari perhitungan Korelasi Pearson antara Pertumbuhan Ekonomi dan Ketimpangan menurut Williamson dan ketimpangan menurut Theil dapat dithat pada tabel 4 di bawah ini. 
Diana Wijayanti dan Arief Eko Pratono: Pertumbuhan Ekonomi dan Ketimpangan...
Tabel 4
Hasil Perhitungan Korelasi Pearson Indeks Williamson

\begin{tabular}{|l|c|}
\hline Indeks Williamson & 0.5764764 \\
\hline Indeks Enteropi Theil & 0.5457845 \\
\hline
\end{tabular}
Sumber : Data BPS, diolah
Menurut Definisi dari Korelasi Pearson, apabila rmendekati + 1 ataupun - 1 dikatakan hubungan Pertumbuhan Ekonomi dengan Ketimpangan berpengaruh kuat, dan apabila $r$ mendekati atau sama dengan 0 maka dapat dikatakan hubungannya lemah atau tidak ada sama sekali. -Dari datá pada tabel 4.4 diatas, dapat disimpulkan bahwa Pertumbuhan Ekonomi diwilayah Kabupaten Klaten menunjukan hubungan yang positif dan kuat terhadà Ketimpangan Pendapatan antar Kecamatan di Kabupaten Klaten. Apabila pertumbuhan Ekonomi diwilayah Klaten meningkat maka ketimpangan yang terjadi juga meningkat, apabila Pertumbuhan Ekonomi diwilayah Klaten menurun maka Ketimpangan yang terjadi antar wilayah kecamatan juga turun.

\section{E. KESIMPULAN}

Menurut Tipologi Daerah, yang diambil dari rata-rata PDRB dan rata-rata pertumbuhan PDRB tiap kecamatan di Kabupaten Klaten, Sebagian besar kecamatan di kabupaten Klaten masuk pada daerah yang relatif maju tapi tertékan. Hal ini dikarenakan kecamatan-kecamatan tersebut terletak sebagai - jalur alternatif antar kabupaten. Dan pembangunan di daerah ini mungkin cepat, namun pertumbuhan ekonominya akan terus bertahan atau naik secara perlahan.

Menurut Indeks Williamson, ketimpangan di kabupaten Klaten mengalami peningkatan. Hal ini disebabkan pembangunan terpusat dan terfokus pada lokasilokasi yang memiliki potensi. Hal lain juga dapat dilihat bahwa salah satu faktor penyebab ketimpangan adalah perbedaan letak demografis daerah/kecamatan, yang menyebabkan pembangunan hanya dapat dilakukan didaerah-daerah yang mudah dijangkau. Selain itu penyebab ketimpangan menurut saya adalah adanya kenaikan harga BBM dan adanya bencana alam seperti gempa bumi. Dengan naiknya BBM, daerah yang memiliki potensi ekonomi tinggi turun akibat berkurangnya permintaan antar daerah dan pembangunan yang terjadi melambat dan bahkan ada yang berkurang. Dengan adanya bencana alam gempa bumi, pembangunan lebih terfokus pada daerah yang terkena dampak gempa.

Menurut Indeks Enteropi Theil, ketimpangan kabupaten Klaten mengalami peningkatan. Hal ini disebabkan oleh pendapatan dari tiap daerah berbedabeda, dan sumber daya yang terdapat di tiap daerah juga berbeda. Menurut saya peningkatan $B B M$, dan gempa bumi juga mempengaruhi ketimpangan. Dengan adanya peningkatan BBM, daerah yang tadinya memiliki pendapatan di industri mulai mengalami penurunan. Dengan menurunnya permintaan, bahkan tak jarang gulung tikar, membuat pendapatan di daerah yang lebih mengunggulkan industri mengalami penurunan pendapatan. Berbeda dengan daerah yang 
mengandalkan perdagangan dan pertanian. Dengan adanya gempa bumi, beberapa daerah yang terkena efek dan dampak gempa mendapat tambahan dana dari investor untuk memajukan kembali pendapatan daerahnya agar kembali produktif. Maka mulai timbul industri-industri baru namun sekalanya untuk memenuhi kebutuhan daerah itu.

Menurut Korelasi Pearson, hasil korelasi ketimpangan Williamson dan Theil memiliki pengaruh yang kuat dan positif terhadap pertumbuhan ekonomi. Dapat dijelaskan bahwa pengaruhnya kuat dan positif adalah apabila ketimpangan mengalami kenaikan, maka pertumbuhan ekonomi akan ikut naik. Apabila ketimpangan yang terjadi turun, maka pertumbuhan ekonomi juga turun.

\section{F. IMPLIKASI KEBIJAKAN}

- Kebijakan ekonomi regional bertujuan untuk mengurangi pertumbuhan dan ketimpangan ekonomi antar daerah. Dalam mengambil kebijakan, sebaiknya pemerintah kabupaten Klaten memiliki beberapa strategi pembangunan yang tepat dan membuat skala prioritas. Beberapa saran yang dapat digunakan untuk mencapai kebijakan tersebut adalah :

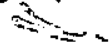

1. Untuk daerah yang laju pertumbuhan PDRB dan tingkat pendapatan perkapita lebih tinggi dan rata-rata seluruh kecamatan (high growth and high income), pemerintah kabupaten Klaten lebih baik bekerja sama dengan investor untuk mengembangkan kecamatan yang nantinya kecamatankecamatan tersebut dapat berkembang dengan sendirinya.

2. Untuk daerah yang laju pertumbuhan PDRB diatas rata-rata laju pertumbuhan kabupaten Klaten namun tingkat pendapatan perkapita berada di bawah rata-rata pendapatan perkapita kabupaten Klaten, pemerintah kabupaten Klaten sebaiknya lebih mendorong kecamatan-kecamatan ini untuk meningkatkan potensi-potensi tiap kecamatan agar pendapatan yang terjadi bisa naik.

3. - Untuk daerah yang laju pertumbuhan PDRB dibawah rata-rata laju pertumbuhan kabupaten Klaten namun tingkat pendapatan perkapita berada diatas rata-rata pendapatan perkapita kabupaten Klaten, pemerintah lebih mendorong penguatan pertumbuhan ekonomi di sektor-sektor yang dapat meningkatkan pertumbuhan ekonomi untuk lebih ditekankan.

4. Untuk daerah yang laju pertumbuhan PDRB dan pendapatan perkapita berada dibawah rata-rata laju pertumbuhan dan pendapatan perkapita, lebih memperhatikan potensi daerah dan keunggulan daerah agar daerahdaerah ini nantinya bisa dikembangkan lebih baik untuk menaikan sektorsektor yang dapat memajukan pendapatan yang ada di kecamatankecamatan. Untuk itu peningkatan pendapatan daerah lebih diperhatikan untuk ditingkatkan setelah pendapatan berhasil meningkat,tiap daerah ini lebih memperhatikan bagaimana cara untuk meningkatkan pertumbuhan ekonomi. 
Akita, Takahiro \& Armida S Alisjahbana, 2002, "Regional Income Inequality in Indonesia and the Initial Impact of the Economic Crisis", Bulletinof Indonesian Studies, Vol. 38, No. 2.

Akita, Takahiro \& Rizal Affandi Lukman, 1995," Interregional Inequalities in Indonesia.A Sectoral Decomposition Analysis for 1975-1992", Buletin of Indonesian Economic Studies, Vol 31, no 2, Agustus

Akita, Takahiro \& Kazumi Kawamura, 2000, "Regional Income in China and Indonesia AComparative Analysis", Economic Research Institute for Northeast Asia.

Arsyad, Lincolyn. (2004), Ekonomi Pembangunan, Yogyakatta, STIE YKPN.

Adisasmita, Rahardjo, H (2005). Dasar-Dasar Ekonomi Wilayah. Graha llmu, Yogyakarta.

Boediono, (1999), Ekonomi Moneter: seri sinopsis Pengantar Ilmu Ekonomi no.5 BPFE. Yogyakarta.

Departemen Dalam Negeri dan Lembaga Administrasi Negara (2007), Modul Perspektif Pembangunan Ekonomi Regional, Jakarta.

Hakim, Abdul. (2002), "Ekonomi Pembangunan Edisi Pertama”. Yogyakarta: Ekonisia.

Imelia dan Emilia (2006), Modul Ekonomi Regional, Fakultas Ilmu Ekonomi, Universitas Jambi,.

Jhingan. (2000), Ekonomi Pembangunan dan Perencanaan. Jakarta, Rajawali Press.

Kuncoro, M. (2002). Analisis Spasial dain Regional: Studi Aglomerasi dan Kluster Industri Indonesia. Yogyakarta: UPP-AMP YKPN

Kuncoro, M. (2004). Otonomi Dan Pembangunan Daerah. Jakarta: Erlangga, P, Gerardo. dan H.W Arndt (terj.) (1991), IImu Ekonomi, LP3ES Jakarta. Saleh, Samsubar. (2004), Statistik Deskriptif, Yogyakarta, UPP AMP YKPN. Sukirno, Sadono. (1994). Pengantar Teori Makro Ekonomi. Jakarta: PT. Raja Grafindo Persada. 
Ying, Long Cen, (2000), China's Changing Regional Disparites during the Reform Period, Economic Geography.

Wijaya, Arif. (2007), Pertumbuhan Ekonomi dan Ketimpangan Antar kecamatan di Kabupaten Kudus tahun 1999-2004, Skripsi Sarjana (Tidak dipublikasikan), Fakultas Ekonomi, Universitas Islam Indonesia, Yogyakarta.

Wikestri. (2007), Pertumbuhan Ekonomi dan Ketimpangan Antar kecamatan di Kabupaten Tangerang tahü 2000 - 2004, Skripsi Sarjana (Tidak dipublikasikan), Fakultas Ekonomi, Universitas Islam Indonesia, Yogyakarta. 